\title{
Kewenangan Mahkamah Konstitusi dalam Menguji Peraturan Pemerintah Pengganti Undang-Undang
}

\author{
Riri Nazriyah \\ Fakultas Hukum Universitas Islam Indonesia \\ Jl. Tamansiswa No. 158 Yogyakarta \\ ririesnaya@yahoo.co.id
}

\begin{abstract}
This research is focused on the competency of Constitutional Court to review Perpu. The analyzed problem is judicial review by Constitutional Court over Perpu. This research is a normative research. The characteristic of this research is prescriptive research, which is a research purposed to obtain suggestions on how to solve the problem. The research approach applied in this research includes statute approach and case approach. The data used in the research is secondary data. The result of this research is that Constitutional Court has competency to perform judicial review over Perpu, although Constitution does not clearly grant authority to Constitutional Court. Consideration used by Constitutional Court judges to review Perpu is teleological and sociological factor due to developing society needs.
\end{abstract}

Key words: Competency, examination, vacuum of law

\begin{abstract}
Abstrak
Penelitian ini difokuskan kepada kewenangan Mahkamah Konstitusi untuk menguji Perpu. Permasalahan yang dikaji, judicial review Mahkamah Konstitusi terhadap Peraturan Pemerintah Pengganti UndangUndang (Perpu). Penelitian ini merupakan penelitian yang bersifat normatif. Bentuk penelitian ini ialah penelitian preskriptif, yaitu penelitian yang ditujukan untuk mendapatkan saran-saran mengenai apa yang harus dilakukan guna mengatasi masalah. Pendekatan penelitian yang digunakan meliputi pendekatan undang-undang, dan pendekatan kasus. Jenis data yang digunakan adalah data sekunder. Analisa yang digunakan dalam penelitian ini adalah deskriptif kualitatif. Hasil penelitian ini adalah Mahkamah Konstitusi mempunyai kewenangan untuk melakukan pengujian terhadap Perpu meskipun secara yuridis UUD 1945 tidak memberikan kewenangan secara tegas untuk mengujinya. Pertimbangan yang digunakan oleh hakim konstitusi untuk menguji Perpu adalah faktor teleologis dan sosiologis karena kebutuhan masyarakat yang terus berkembang.
\end{abstract}

Kata kunci : Kewenangan, menguji, kekosongan hukum 


\section{Pendahuluan}

Pada 21 September 2009 Presiden Susilo Bambang Yudhoyono menerbitkan Peraturan Pemerintah Pengganti Undang-Undang Republik Indonesia (Perpu) Nomor 4 Tahun 2009 tentang Perubahan atas Undang-Undang Nomor 30 Tahun 2002 tentang Komisi Pemberantasan Korupsi (KPK). Perpu itu memberikan kewenangan kepada Presiden untuk mengangkat anggota sementara pimpinan KPK bila terjadi kekosongan keanggotaan pimpinan KPK sehingga pimpinannya kurang dari tiga orang.

Perpu Nomor 4 Tahun 2009 diterbitkan melalui pertimbangan: a) bahwa terjadinya kekosongan keanggotaan Pimpinan Komisi Pemberantasan Korupsi telah mengganggu kinerja serta berpotensi menimbulkan ketidakpastian hukum dalam upaya pencegahan dan pemberantasan tindak pidana korupsi yang dilakukan oleh Komisi Pemberantasan Korupsi; b) bahwa pengaturan mengenai pengisian kekosongan keanggotaan Pimpinan Komisi Pemberantasan Korupsi yang diatur dalam Undang-Undang Nomor 30 Tahun 2002 tentang Komisi Pemberantasan Tindak Pidana Korupsi memerlukan waktu yang cukup lama, sehingga untuk menjaga keberlangsungan dan kesinambungan upaya pencegahan dan pemberantasan tindak pidana korupsi diperlukan percepatan dalam pengisian kekosongan keanggotaan Pimpinan Komisi Pemberantasan Korupsi.

Keberadaan Perpu Nomor 4 tahun 2009 telah menimbulkan kegoncangan dalam masyarakat dan mengguncangkan sistem dan sendi-sendi hukum yang berlaku di Indonesia, karena dinilai bertentangan dengan UUD 1945 dan UU No. 10 tahun 2004 tentang Pembentukan Peraturan Perundang-Undangan. Perhimpunan Advokat Indonesia Pengawal (PAIP) Konstitusi (sebagai pemohon) merasa keberatan terhadap dikeluarkannya Perpu 2009 karena menilai Perpu tersebut tidak sesuai kepastian hukum dan kaidah pembentukan peraturan perundang-undangan serta bertentangan dengan Pasal 28D ayat (1) UUD1945 yang merugikan hak konstitusional para Pemohon.

Akhirnya, Perpu tersebut dibawa ke MK untuk dimohonkan uji materi. Dapatkan MK menguji Perpu? Ada yang mengatakan tidak dapat diuji materi oleh MK. Bahkan, Ketua MK, Moh. Mahfud MD pernah mengatakan secara tegas soal itu. Menurut Mahfud, Perpu hanya boleh diuji dengan political review di DPR bukan judicial review ke MK. Ini diperkuat oleh ketentuan letterlijk Pasal 24C UUD 1945 yang menyebut MK berwenang untuk menguji undang-undang terhadap UUD. ${ }^{1}$

${ }^{1}$ Kompas, 29 September 2009. Meski akhirnya Mahfud MD menyatakan bahwa, Perpu dapat diuji konstitusionalitasnya oleh MK antara lain karena perkembangan dalam ketatanegaraan Indonesia, terutama melalui 
Hakim konstitusi Akil Mochtar mengatakan, MK mempunyai peluang yang cukup terbuka untuk menguji peraturan pemerintah pengganti undang-undang. MK tidak boleh terpaku dengan ketentuan, perpu hanya bisa diuji melalui political review oleh Dewan Perwakilan Rakyat (DPR) karena MK harus mampu mengikuti perkembangan hukum ketatanegaraan. MK sebagai pengawal konstitusi sekaligus pelindung hak konstitusional warga negara seharusnya dapat menguji Perpu. Apalagi, saat ini tidak ada lembaga negara yang dapat mengontrol penerbitan Perpu. ${ }^{2}$

MK dalam putusannya terdahulu memang menyatakan, penerbitan Perpu adalah hak subjektif Presiden. Ini sesuai dengan Pasal 22 UUD 1945 yang memberikan kewenangan kepada Presiden jika ada kegentingan memaksa. Namun, tidak ada satu ketentuan pun mengenai kriteria kegentingan memaksa baik di UUD 1945 maupun undang-undang. "Perpu memang dibahas oleh DPR pada masa sidang berikutnya. Bisa diterima atau ditolak. Meskipun demikian, tidak dijelaskan masa sidang mana. Padahal, penerbitan Perpu yang menyebabkan terjadinya kerugian konstitusional warga negara sejak Perpu itu diterbitkan sangat memungkinkan. Maka tugas MK melindungi hak konstitusional warga." 3

Senada dengan itu Taufiqurrohman Syahuri dan Charles Simabura, menilai bahwa Perpu dapat dibawa ke MK, karena secara materiil, Perpu sama dengan undang-undang. ${ }^{4}$ Sedangkan Bagir Manan menilai, Perpu No 4 tahun 2009 adalah prematur, perpu itu dikhawatirkan akan menimbulkan komplikasi hukum di kemudian hari. Perpu semestinya cuma mengatur ranah eksekutif atau pemerintahan. Tidak bisa menyangkut soal kelembagaan negara semacam DPR atau Mahkamah Agung (MA) termasuk Komisi Pemberantasan Korupsi (KPK) sebagai lembaga independen. Jika Perpu yang dikeluarkan menyangkut langsung keberadaan lembaga negara atau lembaga independen lain, itu akan menghilangkan esensi independensi lembaga itu. ${ }^{5}$

titik tekan dalam penafsiran konstitusi. Menurut Ketua MK, perkembangan ketatanegaraan saat ini menunjukkan perlunya penafsiran atas isi UUD 1945 yang tidak hanya bertumpu pada tafsir historik dan gramatik, tetapi juga berdasarkan pada tafsir telologis dan sosiologis yang berkembang di masyarakat.Lihat http://www.antara.co.id/ berita/1265672941/mahfud-mk-dapat-uji-konstitusionalitas-perpu.

${ }^{2}$ http://jakarta45.wordpress.com. Di akses tanggal 30 Juni 2010.

${ }^{3}$ Ibid.

${ }^{4}$ Ibid.

${ }^{5}$ Ibid. 


\section{Rumusan Masalah}

Berdasarkan uraian di atas, permasalahan yang menarik untuk dikaji adalah dapatkah Mahkamah Konstitusi melakukan judicial review terhadap Perpu jika dianggap bertentangan dengan UUD 1945?

\section{Tujuan Penelitian}

Penelitian ini bertujuan untuk mengetahui kewenangan Mahkamah Konstitusi dalam melakukan judicial review terhadap Perpu sebagai produk hukum buatan Presiden, jika dianggap bertentangan dengan UUD 1945.

\section{Metode Penelitian}

Penelitian ini merupakan penelitian yang bersifat normatif. Bentuk penelitian ini ialah penelitian preskriptif, yaitu penelitian yang ditujukan untuk mendapatkan saran-saran mengenai apa yang harus dilakukan guna mengatasi masalah. ${ }^{\text {Pendekatan }}$ penelitian yang digunakan meliputi pendekatan undang-undang, dan pendekatan kasus. Jenis data yang digunakan adalah data sekunder. Sumber data sekunder yang digunakan mencakup bahan hukum primer, bahan hukum sekunder dan bahan hukum tersier. Teknik pengumpulan data yang digunakan berupa bahan pustaka melalui dokumen resmi (putusan), buku-buku literatur, peraturan perundang-undangan, serta pengumpulan data, melalui media elektronik yang berhubungan dengan masalah yang diteliti. Analisa yang digunakan dalam penelitian ini adalah deskriptif kualitatif, yaitu menganalisis data yang ada untuk selanjutnya dikaji dan diinterpretasikan oleh peneliti untuk mendapatkan kesimpulan yang diharapkan.

\section{Hasil dan Pembahasan}

\section{Peraturan Pemerintah Pengganti Undang-Undang}

Perpu adalah suatu peraturan yang dibentuk oleh Presiden dalam hal ikhwal kegentingan yang memaksa, dalam arti pembentukannya memerlukan alasan-alasan

${ }^{6}$ Sorjono Soekanto, Pengantar Penelitian Hukum, Cetakan Ketiga, UI-Press, Jakarta, 1986, hlm. 10. 
tertentu, yaitu adanya keadaan mendesak, memaksa atau darurat yang dapat dirumuskan sebagai keadaan yang sukar atau sulit dan tidak tersangka-sangka yang memerlukan penanggulangan yang segera. Kriteria tentang apa yang dimaksudkan dengan istilah hal ikhwal kegentingan yang memaksa adalah suatu keadaan yang sukar, penting dan terkadang krusial sifatnya, yang tidak dapat diduga, diperkirakan atau diprediksi sebelumnya, serta harus ditanggulangi segera dengan pembentukan peraturan perundang-undangan yang setingkat dengan undang-undang. ${ }^{7}$

Keadaan bahaya tidak boleh berlama-lama, karena fungsi utama hukum negara darurat (staatsnoodrecht) ialah menghapuskan segera bahaya itu sehingga kembali normal. Bila terjadi keadaan berlama-lama, nood (bahaya) itu maka menyalahi tujuan diadakan hukum negara darurat. Keadaan bahaya dengan upaya luar biasa harus ada keseimbangan, supaya kewenangan itu tidak berkelebihan sekaligus mencegah penyalahgunaan kekuasaan yang besar. Keadaan bahaya itu adalah sesuatu yang abnormal, untuk mengatasi bahaya itu hukumnya pun dalam keadaan biasa pun harus dipandang abnormal dan luar biasa, mungkin dalam keadaan normal tindakan penguasa itu masuk dalam kategori onrechtmatig, namun karena keadaan bahaya atau abnormal, maka tindakan Penguasa itu adalah sah dan dapat dibenarkan. ${ }^{8}$

Harus pula dipertimbangkan, bagaimana supaya dalam keadaan bahaya (staatsnoodrecht) hak-hak asasi manusia tetap dihargai sebagaimana layaknya. Demikian juga UUD dan hukum lain yang mungkin tidak dihapuskan seluruhnya, dalam waktu singkat dan sementara saja dan bukan untuk selamanya. ${ }^{9}$

Menurut Maria Farida Indrati Soeprapto,${ }^{10}$ karena Perpu ini merupakan PP yang menggantikan kedudukan undang-undang, materi-muatannya adalah sama dengan materi-muatan dari undang-undang. Hal yang sama dikemukakan oleh Bagir Manan, ${ }^{11}$ yang dimaksud dengan pengganti undang-undang adalah bahwa materi muatan Perpu merupakan materi muatan undang-undang. Dalam keadaan biasa (normal) materi muatan tersebut harus diatur dengan undang-undang.

${ }^{7}$ I Gde Pantja Astawa, "Ruang Lingkup dan Pelaksanaan Wewenang Presiden Berdasarkan Ketentuan UndangUndang Dasar 1945”, Bandung, Thesis Ilmu Hukum Program Pascasarjana Universitas Padjadjaran, 1992, hlm. 178179. Dalam dan Suprin Na'a, Dinamika Hukum dan Ilmu Perundang-undangan di Indonesia, Cetakan ke 1, PT. Alumni Bandung, 2008, hlm. 99-100

${ }^{8}$ R. Kranenburg, De Grondslagen der Rechtswetenschap, Cetakan ketiga, 1951, hlm. 94-96, sebagaimana dikutip kembali oleh Herman Sihombing dalam Hukum Tata Negara Darurat di Indonesia, Djambatan, Jakarta, 1996, hlm. viii.

${ }^{9}$ A.A.L.F. Van Dullemen, Staatsnoodrecht en Democratie 1947, dikutip kembali oleh Herman Sihombing, Ibid., hlm. 7 . 
Justru itu, Pasal 9 UU No. 10 Tahun 2004 tentang Pembentukan Peraturan Perundang-undangan memberi ketegasan bahwa, materi muatan Perpu sama dengan materi muatan undang-undang. Karena memang Perpu adalah undang-undang yang dibentuk seperti PP.

Sebagai peraturan darurat, Perpu mengandung pembatasan-pembatasan. Pertama: Perpu hanya dikeluarkan dalam hal ikhwal kegentingan yang memaksa. Dalam praktik hal ikhwal kegentingan yang memaksa sering diartikan secara luas. Tidak hanya terbatas pada keadaan yang mengandung suatu kegentingan atau ancaman, tetapi termasuk juga kebutuhan yang dipandang mendesak. Siapakah yang menentukan kegentingan yang memaksa itu? Karena kewenangan menetapkan Perpu ada pada Presiden, Presidenlah yang secara hukum menentukan kegentingan yang memaksa. ${ }^{12}$ Kedua, Perpu hanya berlaku untuk jangka waktu yang terbatas. Presiden -paling lambat dalam masa sidang DPR berikutnya- harus mengajukan Perpu ke DPR untuk memperolah persetujuan. Apabila disetujui DPR, Perpu berubah menjadi undang-undang. Kalau tidak disetujui, Perpu tersebut harus segera dicabut.

Pembatasan jangka waktu dan persetujuan DPR mengandung berbagai makna: (1) kewenangan membuat Perpu memberikan kekuasaan luar biasa kepada Presiden. Kekuasaan luar biasa ini harus dikendalikan untuk menghindari penyalahgunaan kekuasaan dengan mempergunakan Perpu sebagai sarana; (2) telah dikemukakan, materi muatan Perpu merupakan materi muatan UU. Karena itu, harus diajukan kepada DPR agar mendapatkan persetujuan untuk menjadi UU; (3) Perpu mencerminkan suatu keadaan darurat. Keadaan darurat merupakan pembenaran untuk misalnya menyimpangi prinsip-prinsip negara berdasarkan atas hukum atau prinsip negara berkonstitusi. Pengajuan Perpu secepat mungkin kepada DPR berarti secepat mungkin pula pengembalian pada keadaan normal yang menjamin pelaksanaan prinsip-prinsip negara berdasar atas hukum atau negara berkonstitusi. ${ }^{13}$

${ }^{10}$ Maria Farida Indrati Soeprapto, Ilmu Perundang-undangan; Dasar-Dasar dan Pembentukannya, Kanisius, Yogyakarta, 1998, hlm. 131.

${ }^{11}$ Bagir Manan, Dasar-Dasar Perundang-undangan Indonesia, Ind-Hill.Co, Jakarta, 1992, hlm. 50.

${ }^{12}$ Pasal 12 UUD 1945 mempersyaratkan ditentukan syarat-syarat objektif untuk pemberlakuan, pengawasan, dan pengakhiran suatu keadaan bahaya itu, sedangkan Pasal 22 UUD 1945 tidak menentukan adanya syarat-syarat objektif semacam itu, kecuali menyerahkan pelaksanaan sepenuhnya kepada Presiden untuk menilai apakah kondisi negara berada dalam keadaan genting dan memaksa atau terdapat hal ikhwal kegentingan yang bersifat memaksa untuk ditetapkan suatu peraturan pemerintah pengganti undang-undang (Perpu). Dengan perkataan lain, Pasal 12 mengatur mengenai keadaan yang bersifat objektif, sedangkan Pasal 22 mengatur mengenai tindakan pengaturan yang harus dilakukan oleh Presiden atas dasar penilaian subjektifnya mengenai keadaan negara. Lihat Jimly Asshiddiqie, Hukum Tata Negara Darurat, Raja Grafindo Persada, Jakarta, 2007, hlm. 208-209.

${ }^{13}$ I Gde Pantja Astawa dan Suprin Na'a, Dinamika Hukum.... Op., Cit., hlm. 101-102 ‥ 
Mengenai kedudukan Perpu memang sering dipersoalkan apakah masih akan dipertahankan. Dengan sebutan yang berbeda, baik dalam Pasal 139 ayat (1) konstitusi Republik Indonesia Serikat 1949 maupun dalam Pasal 96 UUDS 1950, bentuk peraturan demikian selalu ada, yaitu dengan sebutan Undang-Undang Darurat. Pasal 139 ayat (1) Konstitusi RIS 1949 menyatakan,Pemerintah berhak atas kuasa dan tanggung jawab sendiri menetapkan undang-undang darurat untuk mengatur hal-hal penyelenggaraan pemerintahan federal yang karena keadaan-keadaan yang mendesak perlu diatur dengan segera. Ketentuan yang diadopsi dalam UUD 1950 Pasal 96 ayat (1) menegaskan,"Pemerintah berhak atas kuasa dan tanggung jawab sendiri menetapkan undang-undang darurat untuk mengatur hal-hal penyelenggaraan pemerintahan yang karena keadaan-keadaan yang mendesak perlu diatur dengan segera" ${ }^{14}$ Ayat (2) mengatakan bahwa, Undang-undang darurat mempunyai kekuasaan dan derajad undangundang, ketentuan ini tidak mengurangi yang ditetapkan dalam pasal yang berikut.

Kedua ayat dari pasal tersebut nampak bahwa untuk menyebut peraturan sebagaimana yang dimaksud dengan Perpu menurut UUD 1945 dipergunakan "Undang-Undang Darurat". Pemakaian Undang-undang darurat seringkali dikacaukan dengan yang dimaksud dengan Undang-undang tentang Keadaan darurat/Bahaya. ${ }^{15}$

Undang-undang darurat atau Perpu adalah dimaksudkan menyebut suatu peratutan berderajad undang-undang sebagai gantinya undang-undang yang dibuat dalam hal ikhwal yang perlu segera diatur, sehingga tidak perlu menunggu persetujuan DPR dulu. Undang-undang tentang keadaan darurat adalah suatu undang-undang yang mengatur manakala ada keadaan bahaya, baik mengatur tentang syarat-syaratnya kapan boleh dinyatakan ada keadaan bahaya maupun akibat-akibat hukumnya setelah dinyatakan adanya keadaan bahaya itu. ${ }^{16}$

Dalam UUD 1945 ketentuan mengenai ini diatur dalam dua pasal, yaitu Pasal 12 dan Pasal 22. Pasal 12 menegaskan,"Presiden menyatakan keadaan bahaya. Syaratsyarat dan akibatnya keadaan bahaya ditetapkan dengan undang-undang."Pasal 22 ayat (1) menyatakan "Dalam hal ikhwal kegentingan yang memaksa, Presiden berhak menetapkan peraturan pemerintah sebagai pengganti undang-undang." Dari ketentuan tersebut, dapat diketahui adanya dua kategori keadaan menurut UUD 1945 yaitu: keadaan bahaya dan hal ikhwal kegentingan yang memaksa.

\footnotetext{
${ }^{14}$ Ibid., hlm. 205.

${ }^{15}$ Ni'matul Huda, Hukum Tata Negara, Cetakan Pertama, Gama Media kerja sama Pusat Studi Hukum Fakultas Hukum Universitas Islam Indonesia, Yogyakarta, 1999, hlm. 70.

${ }^{16}$ Ibid., hlm. 70- 71.
} 
Istilah yang dipakai dalam kedua pasal tersebut jelas berbeda. Istilah yang pertama menggunakan istilah "keadaan bahaya" yang tidak lain sama dengan pengertian keadaan darurat (state of emergency). Istilah kedua memakai istilah "hal ikhwal kegentingan yang memaksa." Apakah kata "hal ikhwal" sama dengan pengertian "keadaan" ? Keduanya tentu tidak sama. Keadaan adalah strukturnya, sedangkan hal ikhwal adalah isinya. Namun, dalam praktik, keduanya dapat mengandung makna praktis yang sama. Oleh karena itu, keadaan bahaya kadangkadang dianggap sama dengan hal ikhwal yang membahayakan, atau sebaliknya hal ikhwal yang membahayakan sama dengan keadaan bahaya. ${ }^{17}$

Hanya saja, apakah hal ikhwal kegentingan yang memaksa itu selalu membahayakan? Segala sesuatu yang "membahayakan" tentu selalu memikili sifat yang menimbulkan "kegentingan yang memaksa", tetapi segala hal ikhwal kegentingan yang memaksa tidak selalu membahayakan. Jika demikian, berarti kondisi kegentingan yang memaksa itu lebih luas daripada keadaan bahaya. Oleh karena itu, kedua istilah "keadaan bahaya" dan "hal ikhwal kegentingan yang memaksa" tersebut dapat dibedakan satu dengan yang lain. Adanya pembedaan itu, wajar apabila penetapan suatu peraturan pemerintah sebagai undang-undang berdasarkan ketentuan Pasal 22 ayat (1) UUD 1945 tidak harus didahului oleh suatu deklarasi keadaan darurat. Pelaksanaan ketentuan Pasal 12 UUD 1945 mempersyaratkan dilakukanknya deklarasi atau proklamasi resmi dalam rangka pemberlakuan keadaan bahaya itu. ${ }^{18}$

Tidak setiap kali Presiden menetapkan peraturan pemerintah pengganti undangundang berarti negara berada dalam keadaan bahaya. Keadaan bahaya dapat dianggap sama dengan hal ikhwal yang membahayakan, atau sebaliknya, hal ikhwal yang membahayakan juga merupakan keadaan yang membahayakan. Hal ikhwal keadaan yang memaksa itu tidak selalu membahayakan. Segala sesuatu yang "membahayakan" tentu selalu bersifat "kegentingan yang memaksa," tetapi segala hal ikhwal kegentingan yang memaksa tidak selalu membahayakan. Oleh karena itu, dalam keadaan bahaya menurut Pasal 12, Presiden dapat menetapkan Perpu kapan saja diperlukan, tetapi, penetapan Perpu oleh Presiden tidak selalu harus berarti ada keadaan bahaya lebih dulu. Artinya, dalam kondisi negara dalam keadaan normal pun, apabila memang memenuhi syarat, Presiden dapat saja menetapkan suatu Perpu. ${ }^{19}$

\footnotetext{
${ }^{17}$ Jimly Asshiddiqie, Hukum Tata Negara..., Op.Cit., hlm. 206.

${ }^{18}$ Ibid.

${ }^{19}$ Ibid., hlm. 207
} 
Undang-Undang Darurat yang digunakan dalam Konstitusi RIS 1949 maupun UUDS 1950 Dasar hukumnya adalah keadaan darurat yang memaksa (emergensi), baik karena keadaan bahaya ataupun karena sebab lain yang sungguh-sungguh memaksa. Jadi, tidak benar jika dikatakan bahwa dasar hukumnya hanya keadaan darurat menurut ketentuan keadaan bahaya yang dikaitkan dengan pemberlakuan keadaan staatsnoodrect (hukum negara dalam keadaan bahaya) atau mengenai noodverordeningsrect Presiden. Di samping keadaan bahaya itu, dapat saja terjadi karena alasan-alasan mendesak, misalnya untuk memelihara keselamatan negara dari ancaman-ancaman yang tidak boleh dibiarkan berlarut-larut, sementara proses di DPR tidak dapat dilaksanakan, maka Presiden atas dasar keyakinannya dapat saja menetapkan peraturan mengenai materi yang seharusnya dimuat dalam undangundang itu dalam bentuk Perpu. ${ }^{20}$

Harus diingat bahwa pengertian keadaan memaksa yang bersifat longgar tersebut harus pula diimbangi dengan pengertian bahwa sebagai konsekuensi bergesernya kekuasaan membentuk undang-undang dari Presiden ke DPR berdasarkan ketentuan Pasal 20 ayat (1) baru juncto Pasal 5 ayat (1) baru UUD 1945, maka kedudukan DPR sebagai lembaga legislatif makin dipertegas. Oleh karena itu, semua peraturan yang dikeluarkan oleh Presiden haruslah mengacu kepada undang-undang dan UUD, dan tidak boleh lagi bersifat mandiri dalam arti tidak untuk melaksanakan perintah undang-undang adalah berbentuk Perpu yang dapat berlaku selama-lamanya 1 tahun. Untuk selanjutnya Perpu tersebut harus diajukan untuk mendapatkan persetujuan DPR. Jika DPR menolak menyetujui Perpu tersebut, maka menurut ketentuan Pasal 22 ayat (3) UUD 1945 Presiden harus mencabutnya kembali dengan tindakan pencabutan. ${ }^{21}$

\section{Kewenangan Mahkamah Konstitusi dalam Menguji Perpu}

Ide untuk membentuk MK yang salah satu tugasnya antara lain meninjau kembali keabsahan perudang-undangan sebagai sarana untuk membatasi penggunaan kekuasaan pemerintah, telah disuarakan oleh para hakim, pengacara

\footnotetext{
${ }^{20}$ Jimly Asshiddiqie, Konstitusi dan Konstitusionalisme Indonesia, Cetakan Pertama, Kerja sama Mahkamah Konstitusi RI dan Pusat Studi Hukum Tata Negara FH UI, Jakarta, 2004, hlm. 273-274. Lihat juga Joeniarto, Selayang Pandang Sumber-Sumber Hukum Tatanegara di Indonesia, Cetakan kedua, Liberty, Yogyakarta, 1991, hlm. 138.

${ }^{21}$ Ibid.
} 
dan kelompok kelas menengah pada 1966-1967, hanya saja dominasi pemerintah sangat kuat sehingga ide tersebut tidak dapat terealisir. ${ }^{22}$

MK sebagai salah satu pelaku kekuasaan kehakiman mempunyai peranan penting dalam usaha menegakkan konstitusi dan prinsip negara hukum sesuai dengan tugas dan wewenangnya sebagaimana ditentukan dalam UUD 1945.

Wewenang MK sebagaimana tercantum dalam Pasal 24 C ayat (1), ialah menguji undang-undang terhadap Undang-Undang Dasar, memutus sengketa kewenangan lembaga negara yang kewenangannya diberikan oleh UUD, memutus pembubaran partai politik dan memutus perselisihan tentang hasil pemilihan umum. Kewenangan tersebut adalah dalam tingkat pertama dan terakhir dan putusan MK bersifat final, yaitu langsung mempunyai kekuatan hukum tetap dan tidak terdapat upaya hukum untuk mengubahnya.

Selain daripada itu, berdasarkan Pasal 24 C ayat (2), juncto Pasal 7 B MK juga berwenang untuk memeriksa, mengadili, dan memutus mengenai pendapat DPR bahwa Presiden dan/atau Wakil Presiden telah melakukan pelanggaran hukum berupa pengkhianatan terhadap negara, korupsi, penyuapan tindak pidana berat lainnya, atau perbuatan tercela; dan/atau pendapat bahwa Presiden dan/atau Wakil Presiden tidak lagi memenuhi syarat sebagai Presiden dan/atau Wakil Presiden. Perlu dicatat bahwa putusan ini sifatnya tidak final karena tunduk pada (subject to) putusan Majelis Permusyawaratan Rakyat, lembaga politik yang berwenang memberhentikan Presiden (Pasal 7 A). Jadi, berbeda dengan di Amerika Serikat yang mendahulukan proses politik daripada proses hukum. ${ }^{23}$

Dalam perkembangannya kewenangan MK sekarang bertambah satu lagi yaitu memutus sengketa Pilkada, yang sebelumnya menjadi kewenangan MA. Peralihan kewenangan dari Mahkamah Agung kepada Mahkamah Konstitusi didasarkan pada ketentuan Pasal 236 C UU No. 12 Tahun 2008 tentang Perubahan Kedua Atas UU No. 32 Tahun 2004 tentang Pemerintahan Daerah. Dalam Pasal 236 C UU No. 12 Tahun 2008 disebutkan bahwa:"Penanganan sengketa hasil penghitungan suara pemilihan kepala daerah dan wakil kepala daerah oleh Mahkamah Agung dialihkan

${ }^{22}$ Beny K Herman," Judicial Review dan Perjuangan untuk Tegaknya Konstitusi”, dalam Konstitualisme Peran DPR dan Judicial Review, YLBHI, Jakarta, 1991, hlm. 35-36, dalam Didit Hariadi Estiko Suhartono (Editor), Mabkamah Konstitusi Lembaga Negara Baru Pengawal Konstitusi, Pusat Pengkajian dan Pelayanan Informasi, Sekjen DPRRI, Jakarta, 2003, hlm, 102.

${ }^{23}$ Harun AlRasid, "Hak Menguji Dalam Teori dan Praktek”, artikel dalam Jurnal Konstitusi Vol. 1 Nomor 1 Juli, 2004, hlm. 99. 
kepada Mahkamah Konstitusi paling lama 18 (delapan belas) bulan sejak undangundang ini diundangkan". ${ }^{24}$

Berdasarkan uraian di atas, UUD 1945 sama sekali tidak memberikan kewenangan kepada MK untuk menguji Perpu sebagai produk hukum buatan Presiden, yang dari bentuknya adalah PP, namun dari muatannya adalah muatan UU. Padahal, akhirakhir ini sering timbul perdebatan, apakah penilaian untuk memberi persetujuan atau tidak atas Perpu oleh DPR dilakukan tepat pada masa sidang setelah Perpu dikeluarkan atau bisa kapan saja. Dalam kenyataannya, Perpu yang dimohonkan pengujian dalam perkara ini baru dibahas oleh DPR setelah melampaui masa sidang pertama sejak Perpu ini dikeluarkan. Perpu No. 4 Tahun 2009 diundangkan pada 22 September 2009, sedangkan masa sidang DPR berikutnya (DPR baru, hasil Pemilu 2009) adalah 1 Oktober sampai dengan 4 Desember 2009, tetapi Perpu itu tidak dibahas pada masa sidang tersebut. Jika Perpu tidak dapat diuji oleh MK maka sangat mungkin suatu saat ada Perpu yang dikeluarkan tetapi DPR tidak membahasnya dengan cepat dan mengulur-ulur waktu dengan berbagai alasan, padahal Perpu tersebut mengandung hal-hal yang bertentangan dengan konstitusi. ${ }^{25}$

Untuk itu, dalam salah satu pertimbangannya MK menyatakan bahwa Pasal 22 ayat (1) UUD 1945 menyatakan, "Dalam hal ihwal kegentingan yang memaksa, Presiden berhak menetapkan peraturan pemerintah sebagai pengganti undangundang". Dari rumusan kalimat tersebut jelas bahwa peraturan pemerintah yang dimaksud pada pasal ini adalah sebagai pengganti undang-undang, yang artinya seharusnya materi tersebut diatur dalam wadah undang-undang tetapi karena kegentingan yang memaksa, UUD 1945 memberikan hak kepada Presiden untuk menetapkan Perpu dan tidak memberikan hak kepada DPR untuk membuat peraturan sebagai pengganti undang-undang. Apabila pembuatan peraturan diserahkan kepada DPR maka proses di DPR memerlukan waktu yang cukup lama karena DPR sebagai lembaga perwakilan, pengambilan putusannya ada di tangan anggota, yang artinya untuk memutuskan sesuatu hal harus melalui rapat-rapat DPR sehingga kalau harus menunggu keputusan DPR kebutuhan hukum secara cepat mungkin tidak dapat terpenuhi.

\footnotetext{
${ }^{24}$ Bambang Sutiyoso, Tata Cara Penyelesaian Sengketa di Lingkungan Mabkamah Konstitusi, Cetakan Pertama, UII Press, Yogyakarta, 2009, hlm. 6.

${ }^{25} \mathrm{http}: / /$ www.antara.co.id/berita/1265672941/mahfud-mk-dapat-uji-konstitusionalitas-perpu. diakses tanggal 26 Juni 2010.
} 
Di samping itu, dengan disebutnya "Presiden berhak" terkesan bahwa pembuatan Perpu menjadi sangat subjektif karena menjadi hak dan tergantung sepenuhnya kepada Presiden. Pembuatan Perpu memang di tangan Presiden yang artinya tergantung kepada penilaian subjektif Presiden, meskipun demikian tidak berarti bahwa secara absolut tergantung kepada penilaian subjektif Presiden karena penilaian subjektif Presiden tersebut harus didasarkan kepada keadaan yang objektif yaitu a) adanya keadaan yaitu kebutuhan mendesak untuk menyelesaikan masalah hukum secara cepat berdasarkan undang-undang; b) undang-undang yang dibutuhkan tersebut belum ada sehingga terjadi kekosongan hukum, atau ada undang-undang tetapi tidak memadai; c) kekosongan hukum tersebut tidak dapat diatasi dengan cara membuat undang-undang secara prosedur biasa karena akan memerlukan waktu yang cukup lama sedangkan keadaan yang mendesak tersebut perlu kepastian untuk diselesaikan. Tiga syarat tersebut sebagai parameter adanya kegentingan yang memaksa. ${ }^{26}$

Dalam kasus tertentu dimana kebutuhan akan undang-undang sangatlah mendesak untuk menyelesaikan persoalan kenegaraan yang sangat penting yang dirasakan oleh seluruh bangsa, hak Presiden untuk menetapkan Perpu bahkan dapat menjadi amanat kepada Presiden untuk menetapkan Perpu sebagai upaya untuk menyelesaikan persoalan bangsa dan negara.

Dalam hal dikeluarkannya Perpu No. 4 Tahun 2009 pemohon berpendapat bahwa pertimbangan Presiden Republik Indonesia dalam Perpu No. 4 Tahun 2009 adalah pertimbangan yang bertentangan dengan hukum karena tidak sesuai dengan fakta yang sebenarnya. Pasal 21 ayat (1) UU No. 30 Tahun 2002 menyatakan, "Komisi Pemberantasan Korupsi sebagaimana dimaksud dalam Pasal 3 terdiri atas: 1. Pimpinan KPK yang terdiri dari 5 (lima) anggota Komisi Pemberantasan Korupsi; 2. Tim Penasihat yang terdiri dari 4 (empat) anggota; dan 3. Pegawai KPK sebagai Pelaksana Tugas. 4. Bahwa pada saat dikeluarkannya Perpu No. 4 Tahun 2009, pimpinan KPK yang aktif terdiri dari 2 (dua) orang sedangkan 3 (tiga) orang tidak aktif (diberhentikan sementara) karena sedang menjalani proses hukum karena diduga telah melakukan tindak pidana. Status kepemimpinan di KPK oleh UU 30 Tahun 2002 tetap dinyatakan sebagai pimpinan KPK. Sehingga tidak benar

${ }^{26}$ Putusan Mahkamah Konstitusi No. 138/PUU-VII/2009 tentang Pengujian Perpu No. 4 Tahun 2009 tentang Perubahan Atas Undang-Undang No. 3 Tahun 2002 tentang Komisi Pemberantasan Tindak Pidana Korupsi, hlm. 21. 
pertimbangan Presiden Republik Indonesia yang menyatakan, "terjadiya kekosongaan keanggotaan Pimpinan Komisi Pemberantasan Korupsi". ${ }^{27}$

Pada saat dikeluarkannya Perpu No. 4 Tahun 2009 tanggal 21 September 2009, pimpinan KPK menjadi 8 (delapan) orang yang terdiri dari 2 (dua) orang dengan status aktif, 3 (tiga) orang dengan status non aktif dan 3 (tiga) orang dengan status pimpinan sementara, sehingga bertentangan dengan Pasal 21 ayat (1) UU No. 30 Tahun 2002 yang mengakibatkan tidak adanya kepastian hukum bagi warga negara; Karena tidak adanya kepastian hukum, maka akan merugikan para Pemohon sebagai penegak hukum dan bertentangan dengan UUD 1945, Pasal 28 D ayat (1) yang menyatakan, "Setiap orang berhak atas pengakuan, jaminan, perlindungan, dan kepastian hukum yang adil serta perlakuan yang sama di hadapan hukum".

Menurut Pemohon apabila dihubungkan dengan pengeluaran Perpu oleh Presiden secara jelas dan nyata akan menimbulkan komplikasi hukum, ketidakpastian hukum, kediktatoran konstitusional sehingga sangat bertentangan dengan hakikat yang diamanatkan dalam Pasal 9 ayat (1) UUD 1945 (1) yang menyatakan, "Sebelum memangku jabatannya, Presiden dan Wakil Presiden bersumpah menurut agama, atau berjanji dengan sungguh-sungguh di hadapan Majelis Permusyawaratan Rakyat atau Dewan Perwakilan memenuhi kewajiban Presiden Republik Indonesia (Wakil Presiden Republik Indonesia) dengan sebaik-baiknya dan seadil-adilnya, memegang teguh Undang-Undang Dasar dan menjalankan segala undang-undang dan peraturannya dengan selurus-lurusnya serta berbakti kepada nusa dan bangsa". ${ }^{28}$

Tindakan Presiden tersebut dengan mudahnya mengeluarkan Perpu dapat menjadi preseden buruk dan dapat membahayakan negara, akan berpotensi mudah mengeluarkan Perpu membubarkan organisasi advokat, Perpu pembredelan pers atau Perpu membubarkan MK karena putusan-putusan MK berbeda dengan Presiden (eksekutif), sehingga terkesan negara selalu dalam keadaan genting. Perlu diingat lahirnya KPK karena kegagalan kepolisian dan kejaksaan memberantas korupsi, sehingga perlu lembaga khusus yang memiliki kewenangan yang lebih agar korupsi bisa lebih mudah diberantas, karena akar dari segala permasalahan bangsa ini adalah korupsi. Gagal berantas korupsi sama dengan negara gagal.

Berdasarkan seluruh uraian tersebut di atas telah terbukti bahwa Perpu No. 4 Tahun 2009 dapat dikategorikan sebagai wujud penyalahgunaan kekuasaan (abuse

\footnotetext{
${ }^{27}$ Ibid

${ }^{28}$ Ibid ., hlm. 14.
} 
of power) dan kesewenang-wenangan (arbitrary action), selain itu Perpu tersebut telah melanggar asas kepastian hukum dan merusak sistem hukum. Perpu tersebut melanggar konstitusi yaitu Pasal 22 ayat (1), Pasal 28 D, Pasal 9 UUD 1945. Dengan demikian menurut hukum, Perpu No. 4 Tahun 2009 haruslah dinyatakan tidak sah dan tidak berlaku, bahwa penerbitan Perpu No. 4 Tahun 2009 merugikan hak konstitusional para Pemohon, sehingga bertentangan dengan Pasal 28 D ayat (1) UUD 1945.

Mahkamah berpendapat sebagai berikut: 1. Para Pemohon yang berprofesi sebagai advokat tidak dirugikan hak konstitusionalnya oleh berlakunya Perpu No. 4 Tahun 2009. Jika pun para Pemohon mengalami kerugian, maka kerugian dimaksud tidak bersifat spesifik (khusus) dan aktual atau setidak-tidaknya potensial yang menurut penalaran yang wajar dapat dipastikan akan terjadi; 2 . Tidak ada hubungan sebab-akibat (causal verband) antara kerugian yang didalilkan oleh para Pemohon dengan berlakunya Perpu No. 4 Tahun 2009 yang dimohonkan pengujian; 3. Tidak terdapat jaminan bahwa dengan dikabulkannya permohonan a quo, kerugian konstitusional sebagaimana yang didalilkan tidak lagi terjadi; Berdasarkan uraian di atas, para Pemohon tidak memiliki kedudukan hukum (legal standing) untuk mengajukan permohonan a quo, karena tidak dirugikan oleh berlakunya Perpu No. 4 Tahun 2009. ${ }^{29}$

Berdasarkan pertimbangan hukum dan fakta di atas, Mahkamah berkesimpulan: Mahkamah berwenang untuk memeriksa, mengadili, dan memutus permohonan $a$ quo; para Pemohon tidak mempunyai kedudukan hukum (legal standing) untuk mengajukan permohonan a quo; Pokok permohonan tidak dipertimbangkan. Mahkamah Konstitusi menyatakan permohonan para Pemohon tidak dapat diterima.

Terhadap Putusan Mahkamah ini Hakim Konstitusi Moh. Mahfud MD mempunyai alasan berbeda (concurring opinion) dan Hakim Konstitusi Muhammad Alim mempunyai pendapat berbeda (dissenting opinion):

\section{Hakim Konstitusi Moh. Mahfud MD}

Jika dirunut dari original intent, tafsir historik, tafsir gramatik, dan logika hukum seharusnya MK tidak dapat melakukan pengujian yudisial (judicial review) atas Perpu terhadap UUD 1945. Sebab menurut Pasal 24 C ayat (1) UUD 1945 Mahkamah hanya menguji undang-undang terhadap Undang-Undang Dasar. Kalimat dalam Pasal 24 C

${ }^{29}$ Ibid., hlm. 25 
ayat (1) tersebut sangat jelas hanya menyebut undang-undang dan tidak menyebut Perpu. Seandainya Mahkamah diperbolehkan menguji Perpu tentu UUD menyebut secara eksplisit pembolehan tersebut sebab secara formal UUD 1945 membedakan dan menempatkan secara berbeda penyebutan atau pengaturan antara undang-undang dan Perpu; Undang-Undang diatur dalam Pasal 20 sedangkan Perpu diatur dalam Pasal 22.

Memang benar, dari sudut isi sebuah Perpu itu mengatur materi muatan undangundang. Artinya isi Perpu itu sebenarnya adalah undang-undang yang dibuat dalam kegentingan yang memaksa yang alasan-alasannya merupakan hak subjektif Presiden. Meskipun demikian, justru karena dibuat dalam keadaan genting itulah UUD 1945 melalui Pasal 22 menyatakan bahwa Perpu itu harus mendapat persetujuan dari DPR pada masa sidang berikutnya, yang apabila DPR tidak menyetujuinya maka Perpu itu harus dicabut atau dibatalkan, tetapi apabila DPR menyetujuinya maka Perpu itu ditetapkan menjadi undang-undang. Jadi, kewenangan Mahkamah untuk menguji Perpu yang memang bermaterikan undang-undang itu hanya dapat dilakukan apabila sudah diuji, dinilai, dibahas, atau apapun namanya dalam forum politik di DPR dan DPR menyetujuinya menjadi undang-undang. Jika DPR tidak menyetujui maka Perpu itu dicabut tetapi jika DPR menyetujui maka Perpu itu ditetapkan menjadi undang-undang dan setelah menjadi undang-undang inilah Mahkamah baru dapat melakukan pengujian yudisial atasnya. Di sinilah letak imbangan bagi "keadaan genting" itu; artinya karena Perpu berisi undang-undang tapi dibuat dalam keadaan genting maka DPR harus memberi penilaian atau melakukan pengujian politik (political review) lebih dulu, apakah akan disetujui menjadi undang-undang atau tidak. Kalau sudah menjadi undang-undang barulah dapat diuji oleh Mahkamah.

Kajian-kajian akademik yang pernah berkembang di kampus-kampus pada 20002001 menyebutkan, antara lain, bahwa pengujian Perpu oleh lembaga yudisial (judicial review) atau oleh lembaga lain (seperti yang pernah diberikan kepada MPR oleh Tap MPR No. III/MPR/2000) merupakan "perampasan" atas hak dan kewenangan konstitusional DPR yang diberikan oleh UUD 1945. Sebab sudah sangat jelas, Pasal 22 UUD 1945 memberi hak kepada DPR untuk menilai sebuah Perpu pada persidangan berikutnya, apakah Perpu itu akan disetujui sebagai undang-undang ataukah tidak. Kesamaan level isi antara undang-undang dan Perpu tetap tidak dapat dijadikan alasan bagi lembaga selain DPR untuk menguji konstitusionalitas Perpu 
terhadap UUD 1945; apalagi kalau kesamaan isi itu hanya karena Perpu diartikan sebagai "undang-undang dalam arti materiil," sebab di dalam hukum tata negara semua jenis peraturan perundang-undangan, mulai dari UUD sampai Peraturan Desa, adalah undang-undang dalam arti materiil.

Akhir-akhir ini ada perkembangan penting dalam ketatanegaraan Indonesia sehingga Mahfud MD ikut menyetujui agar Perpu dapat diuji konstitusionalitasnya oleh MK terutama melalui titik tekan dalam penafsiran konstitusi. Dalam kaitan antara perkembangan ketatanegaraan dan pengujian Perpu ini Mahfud MD melihat perlunya penafsiran atas isi UUD 1945 tidak hanya bertumpu pada original intent, tafsir historik, dan tafsir gramatik melainkan harus menekankan pada penafsiran sosiologis dan teleologis. Perkembangan ketatanegaraan di lapangan yang menjadi alasan bagi Mahfud MD untuk menyetujui dilakukannya judicial review terhadap Perpu oleh MK adalah hal-hal sebagai berikut: ${ }^{30}$

Pertama, akhir-akhir ini timbul perdebatan, apakah penilaian untuk memberi persetujuan atau tidak atas Perpu oleh DPR dilakukan pada masa sidang berikutnya tepat pada masa sidang setelah Perpu itu dikeluarkan ataukah pada masa sidang berikutnya dalam arti kapan saja DPR sempat sehingga pembahasannya dapat diulurulur. Dalam kenyataannya Perpu yang dimohonkan pengujian dalam perkara tersebut baru dibahas oleh DPR setelah melampaui masa sidang pertama sejak Perpu ini dikeluarkan. Perpu 4 Tahun 2009 diundangkan pada 22 September 2009, sedangkan masa sidang DPR berikutnya (DPR baru, hasil Pemilu 2009) adalah 1 Oktober sampai dengan 4 Desember 2009, tetapi Perpu tersebut tidak dibahas pada masa sidang pertama tersebut. Kalau Perpu tidak dapat diuji oleh Mahkamah maka sangat mungkin suatu saat ada Perpu yang dikeluarkan tetapi DPR tidak membahasnya dengan cepat dan mengulur-ulur waktu dengan berbagai alasan, padahal Perpu tersebut mengandung hal-hal yang bertentangan dengan konstitusi. Oleh karena itu menjadi beralasan, demi konstitusi Perpu harus dapat diuji konstitusionalitasnya oleh MK agar segera ada kepastian dapat atau tidak dapat terus berlakunya sebuah Perpu.

Kedua, timbul juga polemik tentang adanya Perpu yang dipersoalkan keabsahan hukumnya karena tidak nyata-nyata disetujui dan tidak nyata-nyata ditolak oleh DPR. Dalam kasus ini DPR hanya meminta agar Pemerintah segera mengajukan

${ }^{30}$ Ibid., hlm. 28 
RUU baru sebagai pengganti Perpu. Masalah mendasar dalam kasus ini adalah bagaimana kedudukan hukum sebuah Perpu yang tidak disetujui tetapi tidak ditolak secara nyata tersebut. Secara gramatik, jika memperhatikan bunyi Pasal 22 UUD 1945, sebuah Perpu yang tidak secara tegas mendapat persetujuan dari DPR "mestinya" tidak dapat dijadikan undang-undang atau tidak dapat diteruskan pemberlakuannya sebagai Perpu, tetapi secara politis ada fakta yang berkembang sekarang ini bahwa "kesemestian" tersebut masih dipersoalkan, sehingga sebuah Perpu yang tidak disetujui oleh DPR (meski tidak ditolak secara nyata) masih terus diberlakukan sampai dipersoalkan keabsahan hukumnya karena dikaitkan dengan satu kasus. Dalam keadaan ini menjadi wajar jika Mahkamah diberi kewenangan untuk melakukan pengujian terhadap Perpu.

Ketiga, terkait dengan tidak disetujuinya sebuah Perpu oleh DPR ada juga pertanyaan, sampai berapa lama atau kapan sebuah Perpu yang tidak mendapat persetujuan DPR harus diganti dengan Undang-Undang Pencabutan atau UndangUndang Pengganti. Karena tidak ada kejelasan batas atau titik waktu maka dalam pengalaman sekarang ini ada Perpu yang tidak mendapat persetujuan DPR tetapi RUU penggantinya atau pencabutannya baru diajukan setelah timbul kasus yang berkaitan dengannya. Oleh karena itu menjadi wajar pula, demi tegaknya konstitusi, MK diberi kewenangan untuk melakukan pengujian terhadap Perpu.

Keempat, dapat terjadi suatu saat Perpu dibuat secara sepihak oleh Presiden tetapi secara politik DPR tidak dapat bersidang untuk membahasnya karena situasi tertentu, baik karena keadaan yang sedang tidak normal maupun karena sengaja dihambat dengan kekuatan politik tertentu agar DPR tidak dapat bersidang. Bahkan, dapat juga dalam keadaan seperti itu ada Perpu yang melumpuhkan lembaga-lembaga negara tertentu secara sepihak dengan alasan kegentingan yang memaksa sehingga ada Perpu yang terus dipaksakan berlakunya sementara persidangan-persidangan DPR tidak dapat diselenggarakan. Dengan memerhatikan kemungkinan itu menjadi wajar apabila Mahkamah diberi kewenangan untuk melakukan pengujian atas Perpu.

Berdasarkan hal-hal tersebut Mahfud MD menyetujui Perpu dapat diuji oleh MK melalui penekanan pada penafsiran sosiologis dan teleologis. Penekanan pilihan atas penafsiran yang demikian memang agak mengesampingkan penafsiran historis dan gramatik, bahkan keluar dari original intent ketentuan tentang Perpu sebagaimana diatur di dalam Pasal 22 UUD 1945. Hal ini perlu dilakukan justru untuk melindungi kepentingan original intent pasal-pasal dan prinsip-prinsip lain yang juga ada di dalam 
UUD 1945. Pilihan pandangan ini semata-mata didasarkan pada prinsip dalam menjaga tegaknya konstitusi yakni "tidak boleh satu detik pun ada peraturan perundang-undangan yang berpotensi melanggar konstitusi tanpa bias diluruskan atau diuji melalui pengujian yudisial." Dengan demikian Mahfud MD setuju dengan pendapat tujuh hakim lainnya bahwa Perpu dapat diuji oleh Mahkamah Konstitusi, tetapi khusus permohonan tersebut (Pengujian Peraturan Pemerintah Penganti Undang-Undang Nomor 4 Tahun 2009 tentang Perubahan Atas Undang-Undang Nomor 30 Tahun 2002 tentang Komisi Pemberantasan Tindak Pidana Korupsi) harus dinyatakan tidak dapat diterima (niet onvantklijke verklaard) karena permohonan bersifat kabur (obscuur) dan pemohon tidak mempunyai kedudukan hukum (legal standing).

\section{Hakim Konstitusi Muhammad Alim}

Alasan-alasan ketidakberwenangan Mahkamah Konstitusi menguji Perpu: ${ }^{31}$

Pertama, Pasal 24 C ayat (1) UUD 1945, Pasal 10 ayat (1) huruf a Undang-Undang Nomor 24 Tahun 2003 tentang Mahkamah Konstitusi, Pasal 12 ayat (1) huruf a Undang-Undang Nomor 4 Tahun 2004 tentang Kekuasaan Kehakiman hanya menyebut, "Menguji undang-undang terhadap UUD."

Kedua, Pasal 20 UUD 1945 yaitu kewenangan membentuk undang-undang, begitu pula Pasal 22 A tentang kewenangan membuat Perpu, sudah lebih dahulu ada, karena waktu mengubah Pasal 20 UUD 1945 dilakukan pada Perubahan Pertama (1999) dan khusus ayat (5) pada Perubahan Kedua (2000); Pasal 22 UUD 1945 tidak ada perubahan, sedangkan Pasal 24 C ayat (1) dilakukan pada Perubahan Ketiga (2001), tetapi hanya menyebut, “Menguji undang-undang terhadap Undang-Undang Dasar ;"

Ketiga, pada waktu dirumuskannya Pasal 24 C ayat (1) UUD 1945, tata urutan perundang-undangan Indonesia menurut Tap MPR Nomor III/MPR/Tahun 2000 tentang Sumber Hukum dan Tata Urutan Perundang-Undangan adalah: UUD 1945, Tap MPR, Undang-Undang, Perpu, dst. Meskipun demikian, rumusan Pasal 24 C ayat (1) UUD 1945 hanya memberi kewenangan untuk, “Menguji undang-undang terhadap UUD"; Kewenangan menguji undang-undang (tanpa menyebut Perpu), terhadap Undang-Undang Dasar 1945 dan Perubahannya dan Ketetapan Majelis Permusyawaratan Rakyat yang menurut ketentuan Pasal 5 ayat (1) Tap MPR No. 
III/MPR/Tahun 2000 merupakan kewenangan MPR lalu dialihkan menjadi kewenangan MK berdasarkan Pasal 24 C ayat (1) UUD 1945, hanya sebatas menguji Undang-Undang terhadap UUD1945, tidak termasuk menguji Perpu, tidak termasuk pula menguji Tap MPR. Dengan pemberian kewenangan semula kepada MPR kemudian kepada MK hanya sebatas menguji undang-undang terhadap UUD walaupun waktu itu posisi Perpu di bawah undang-undang, sedangkan posisi Tap MPR di atas undang-undang menunjukkan dengan seterang-terangnya bahwa pembuat UUD, yakni MPR memang hanya menghendaki kewenangan MK untuk menguji undang-undang terhadap UUD;

Keempat, Pasal 24 C ayat (1) UUD 1945 tidak menyebutkan Perpu, berarti hal itu diserahkan kepada DPR untuk menyetujui atau tidak menyetujui suatu Perpu pada sidang berikutnya sesuai ketentuan Pasal 22 ayat (2) UUD 1945. Setelah disetujui menjadi undang-undang barulah dapat diuji ke MK. Perpu tentang Pemberantasan Tindak Pidana Terorisme yang dikeluarkan menyusul peristiwa yang dikenal dengan sebutan peristiwa 'Bom Bali', diuji di MK setelah disetujui DPR menjadi undangundang (Undang- Undang Nomor 16 Tahun 2003 tentang Penetapan Peraturan Pemerintah Pengganti Undang-Undang Nomor 2 Tahun 2002 tentang Pemberlakuan Peraturan Pemerintah Pengganti Undang-Undang Nomor 1 Tahun 2002 tentang Pemberantasan Tindak Pidana Terorisme, Pada Peristiwa Peledakan Bom di Bali Tanggal 12 Oktober 2002, menjadi undang-undang).

Kelima, tata urutan perundang-undangan Indonesia yang sekarang berlaku sesuai ketentuan Pasal 7 Undang-Undang Nomor 10 Tahun 2004 tentang Pembentukan Peraturan Perundang-undangan, yang memosisikan undang-undang dan Perpu pada level yang sama (seperti dalam TAP MPRS XX/ MPRS/1966) itu dibentuk setelah selesainya Perubahan Keempat UUD 1945 (Tahun 2002).

Keenam, perubahan aturan yang lebih rendah tingkatannya dari UUD, misalnya TAP MPR Nomor III Tahun 2000, yang menetapkan tata urutan perundang-undangan yang meletakkan Perpu pada posisi di bawah undang-undang, kemudian UU 10/ 2004 yang memosisikan undang-undang pada level yang sama dengan Perpu dengan menggunakan garis miring (/), tidak dapat mengubah UUD 1945, yakni Pasal 24 C ayat (1) yang hanya menyebut kewenangan MK untuk antara lain menguji undangundang terhadap UUD, tanpa menyebut kewenangan menguji Perpu.

Ketujuh, Pasal 1 ayat (2) UUD 1945 menentukan, “Kedaulatan berada di tangan rakyat dan dilaksanakan menurut UUD". Kewenangan yang diberikan oleh yang 
berdaulat, harus dilaksanakan sesuai dengan UUD, tidak boleh menyimpang dari UUD 1945. Kewenangan MK yang tertera dalam Pasal 24 C ayat (1) UUD 1945 yang hanya sebatas menguji Undang-Undang terhadap UUD, apabila ditambah dengan menguji Perpu, menurut saya dilaksanakan tidak menurut UUD, melainkan dilaksanakan menyimpang dari UUD.

Berdasarkan pertimbangan-pertimbangan di atas Muhammad Alim berpendapat MK tidak berwenang mengadili permohonan tersebut. Jika muatan materi Perpu bukan materi muatan yang seharusnya diatur dalam undang-undang, atau materi muatan Perpu yang di luar kewenangan Presiden, atau jelas-jelas bertentangan dengan konstitusi, misalnya Presiden mengeluarkan Perpu yang materinya membekukan atau membubarkan DPR, karena bertentangan dengan Pasal 7 C UUD 1945, maka MK berwenang mengadili pengujian Perpu, walaupun belum mendapat persetujuan atau penolakan dari DPR dalam persidangan yang berikutnya, apalagi jika materi Perpu itu tetang pembubaran DPR sudah tidak disetujui atau ditolak oleh DPR. Perpu Nomor 4 Tahun 2009 menurut Muhammad Alim isinya masih dalam kewenangan Presiden serta tidak bertentangan dengan UUD 1945, maka Muhammad Alim berpendapat MK tidak berwenang mengadili permohonan tersebut, oleh karena itu permohonan para Pemohon harus dinyatakan tidak dapat diterima.

Meskipun dalam perkara ini MK sependapat dengan pemohon, MK tidak menggunakan alasan sebagaimana yang dikonstruksi oleh para pemohon yang mendasarkan keberwenangan MK menguji konstitusionalitas Perpu lebih karena kedudukan Perpu yang sejajar dengan undang-undang sesuai dengan Pasal 7 ayat (1) UU No. 10 Tahun 2004 tentang Pembentukan Peraturan Perundang-undangan, maka MK berwenang pula mengadili permohonan pengujian Perpu No. 4 Tahun 2009 yang diajukan pemohon. MK memberi makna kontekstual pada UUD dengan interpretasi sosiologis dan teleologis sehingga teks konstitusi yang ada diinterpretasi untuk memenuhi rasa keadilan. MK melakukan penafsiran UUD 1945 tidak sekedar merujuk makna aslinya, tetapi disesuaikan dengan keadaan terkini sehingga menghasilkan keadilan yang substansial. Tidak jarang terobosan yang dilakukan MK menghasilkan putusan yang responsif terhadap kebutuhan hukum yang hidup dalam masyarakat.

Perpu melahirkan norma hukum dan sebagai norma hukum baru akan dapat menimbulkan: (a) status hukum baru, (b) hubungan hukum baru, dan (c) akibat hukum 
baru. Norma hukum tersebut lahir sejak Perpu disahkan dan nasib dari norma hukum tersebut tergantung kepada persetujuan DPR untuk menerima atau menolak norma hukum Perpu, namun demikian sebelum adanya pendapat DPR untuk menolak atau menyetujui Perpu, norma hukum tersebut adalah sah dan berlaku seperti undangundang. Oleh karena dapat menimbulkan norma hukum yang kekuatan mengikatnya sama dengan undang-undang maka terhadap norma yang terdapat dalam Perpu tersebut Mahkamah dapat menguji apakah bertentangan secara materiil dengan UUD 1945. Dengan demikian Mahkamah berwenang untuk menguji Perpu terhadap UUD 1945 sebelum adanya penolakan atau persetujuan oleh DPR, dan setelah adanya persetujuan DPR karena Perpu tersebut telah menjadi Undang-Undang. ${ }^{31}$

Dalam UUD 1945 maupun peraturan perundang-undangan lainnya secara eksplisit tidak ada yang memberikan kewenangan kepada MK untuk menguji Perpu. Meskipun MK tidak bermaksud melakukan perubahan terhadap rumusan UUD 1945 untuk memperluas kewenangannya. Tetapi, dengan menyatakan kewenangannya untuk memeriksa, mengadili, dan memutus Perpu, sesungguhnya MK telah melakukan perubahan pada UUD 1945. MK telah menambah kewenangannya melalui putusan yang diterbitkannya.

Perubahan UUD 1945 yang dilakukan oleh MK melalui putusan tersebut bukanlah sesuatu yang perlu diperdebatkan secara serius, sebab dalam bidang hukum tata negara, merupakan hal yang sering kali terjadi. Penafsiran dalam hal ini judicial interpretation (penafsiran oleh hakim), juga dapat berfungsi sebagai metode perubahan konstitusi dalam arti menambah, mengurangi, atau memperbaiki makna yang terdapat dalam teks undang-undang dasar. Seperti dikemukakan oleh K.C. Wheare, undang-undang dasar dapat diubah melalui (i) formal amandement, (ii) judicial interpretation, dan (iii) constitutional usage and conventions. ${ }^{32}$ Menurut Robert K. Carr dinamika UUD melalui perubahan-perubahan resmi (Formal Amendements), bukan sesuatu yang penting. Dinamika UUD atau Konstitusi justru lebih dipengaruhi bahkan ditentukan oleh perubahan-perubahan tidak resmi, baik melalui konvensi ketatanegaraan maupun putusan hakim..$^{33}$

\footnotetext{
${ }^{31}$ Ibid., hlm. 21

${ }^{32}$ Jimly Asshiddiqie, Pengantar Ilmu Hukum Tata Negara Jilid I, Sekretariat Jenderal Mahkamah Konstitusi, Jakarta, 2005, hlm. 273.

${ }^{33}$ Valina Singka Subekti, Menyusun Konstitusi Transisi Pergulatan Kepentingan dan Pemikiran dalam Proses Perubahan UUD 1945, RajaGrafindo Persada, Jakarta, 2008, hlm. xxiii.
} 


\section{Penutup}

Berdasarkan uraian di atas dapat disimpulkan bahwa, MK mempunyai kewenangan untuk melakukan pengujian terhadap Perpu meskipun secara yuridis UUD 1945 tidak memberikan kewenangan secara tegas untuk mengujinya. Pertimbangan yang digunakan oleh hakim konstitusi untuk menguji Perpu adalah faktor teleologis dan sosiologis karena kebutuhan masyarakat yang terus berkembang. Kewenangan baru yang dimiliki oleh MK untuk menguji Perpu melalui putusannya, dapat dikatakan MK telah melakukan perubahan konstitusi dengan cara judicial interpretation.

\section{Daftar Pustaka}

Asshiddiqie, Jimly, Hukum Tata Negara Darurat, Raja Grafindo Persada, Jakarta, 2007. Pengantars Ilmu Hukum Tata Negara Jilid I, Sekretariat Jenderal Mahkamah Konstitusi, Jakarta, 2005.

, Konstitusi dan Konstitusionalisme Indonesia, Cetakan Pertama, Kerja sama Mahkamah Konstitusi RI dan Pusat Studi Hukum Tata Negara FH UI, Jakarta, 2004.

AlRasid, Harun, "Hak Menguji Dalam Teori dan Praktek", artikel dalam Jurnal Konstitusi Vol. 1 Nomor 1 Juli, 2004.

Farida Indrati Soeprapto, Maria, Ilmu Perundang-undangan; Dasar-Dasar dan Pembentukannya, Kanisius, Yogyakarta, 1998.

Hariadi Estiko Suhartono, Didit (Editor), Mahkamah Konstitusi Lembaga Negara Baru Pengawal Konstitusi, Pusat Pengkajian dan Pelayanan Informasi, Sekjen DPRRI, Jakarta, 2003.

Huda, Ni'matul, Hukum Tata Negara, Cetakan Pertama, Gama Media kerja sama Pusat Studi Hukum Fakultas Hukum Universitas Islam Indonesia, Yogyakarta, 1999.

I Gde Pantja Astawa dan Suprin Na'a, Dinamika Hukum dan Ilmu Perundang-undangan di Indonesia, Cetakan ke 1, PT. Alumni, Bandung, 2008.

Joeniarto, Selayang Pandang Sumber-sumber Hukum Tatanegara di Indonesia, Cetakan kedua, Liberty, Yogyakarta, 1991

K. Herman, Beny," Judicial Review dan Perjuangan untuk Tegaknya Konstitusi", dalam Konstitualisme Peran DPR dan Judicial Review, Jakarta, YLBHI, 1991.

Manan, Bagir, Dasar-Dasar Perundang-undangan Indonesia, Ind-Hill.Co, Jakarta, 1992.

Sihombing, Herman, Hukum Tata Negara Darurat di Indonesia, Djambatan, Jakarta, 1996. 
Singka Subekti, Valina, Menyusun Konstitusi Transisi Pergulatan Kepentingan dan Pemikiran dalam Proses Perubahan UUD 1945, RajaGrafindo Persada, Jakarta, 2008.

Soekanto, Sorjono, Pengantar Penelitian Hukum, Cetakan Ketiga, UI-Press, Jakarta, 1986.

Sutiyoso, Bambang, Tata Cara Penyelesaian Sengketa di Lingkungan Mahkamah Konstitusi, Cetakan Pertama, UII Press, Yogyakarta, 2009.

Putusan Mahkamah Konstitusi Nomor 138/PUU-VII/ 2009 tentang Pengujian Perpu No. 4 Tahun 2009 tentang Perubahan Atas Undang-Undang No. 3 Tahun 2002 tentang Komisi Pemberantasan Tindak Pidana Korupsi

UUD 1945 Setelah Perubahan

Undang-Undang Nomor 24 Tahun 2003 tentang Mahkamah Konstitusi

Kompas, 29 September 2009.

http:/ / www.antara.co.id/berita / 1265672941/ mahfud-mk-dapat-ujikonstitusionalitas-perpu. Di akses tanggal 26 juni 2010

http://jakarta45.wordpress.com. Di akses tanggal 30 Juni 2010 